\title{
The effect of different genotype cattle grazing on the nutrient content of saline grasslands vegetation
}

\author{
Nóra Kovácsné Koncz - Ádám Simon - Béla Béri \\ University of Debrecen Faculty of Agricultural and Food Sciences and Environmental Management, \\ Institute of Animal Science, Debrecen, Hungary \\ koncz.nora@agr.unideb.hu
}

\section{SUMMARY}

Maintaining saline grasslands in good condition, preserving their yield and diversity is important not only for the purpose of nature conservation, but also for farming. Therefore, the primary purpose of our study is to analyse the effect of pasture use of the smaller weight extensive and the larger weight intensive beef cattle on the grassland vegetation and nutrient content. In this way, we can answer the question whether grazing for nature conservation can be achieved with more profitable, more economical and more intense varieties.

The tests were carried out in May 2016 and May 2017, in the Hortobágy National Park (Pap-ere and Zám puszta), where a total of 16 sample areas were analysed. These areas are grazed with extensive beef cattle (Hungarian grey) and mixed genotype of intensive cattle. The associations were selected along a moisture gradient, such as wet salt marsh (Bolboschoenetum maritimi) and drier saline meadow (Beckmannion eruciformis). All the vegetative material collected both years in May was analysed for the following parameters: dry matter, crude protein, crude fibre and life-sustaining net energy content. We compared the effects of medium grazing (0.46 livestock/ha) and abandonment on vegetation and nutrient content

We examined the effect of (i) grazing, (ii) different grasslands (salt marsh, saline meadow) and (iii) grazing of different cattle breeds (Hungarian grey, intensive beef) on the nutrient content of the vegetation of grasslands

Based on our results, it was found that grazing had an impact on crude protein and life-sustaining net energy content. The highest crude protein content $(12.75 \mathrm{~m} / \mathrm{m} \%)$ was obtained in the year 2017 in the area where higher density had been grazed for two years. For the lifesustaining net energy, the highest value (5.05 MJ/kg d.m.) was also obtained in 2017 and the lowest in 2016. Furthermore, it was found that there was no significant difference between the effect of the two cattle breeds on the parameters examined. Significant effects were observed only in the case of life-sustaining net energy: in the area of intensive beef cattle we received a higher value (5.15 MJ/kg body weight) than in the area with extensive beef cattle (4.96 MJ/kg body weight).

Our results have also shown that cattle grazing is of the utmost importance for the maintenance of both wet and mesophilous habitats. Based on our three-year study, we can say that grazing by both extensive and intensive cattle breeds is suitable for the management of saline habitats.

Keywords: moist grassland, grazing, extensive- intensive beef, Hortobágy, nutritional content

\section{INTRODUCTION}

More than 250000 ha of the 1.1 million ha of grasslands in Hungary are covered by nature conservation protection (Ángyán et al. 2003, Kárpáti 2007, Tasi et al. 2014). Therefore, the conservation or restoration of these areas requires the development of a nature conservation and grass management method where it is of paramount importance coordination of agriculture and nature conservation (Valkó et al. 2016). The two most common treatments for these grasslands are mowing and grazing (Tälle et al. 2016, Nagy and Tasi 2017). Traditional grazing plays an important role in nature conservation programs for grassland conservation worldwide (Penksza et al. 2010, 2013, Szabó et al. 2010/2011, 2011, Török et al. 2014).

Grazing requires a thorough planning and needs to be adjusted to local circumstances (Tölgyesi et al. 2015, Halász et al. 2016, Tóth et al. 2016), so comprehensive programs are required: using results of ecological, botanical, agronomic and animal husbandry research.

In addition to the general effects of the grazing process, nature conservation is of particular importance as regards the grazing of certain animal species, and indeed varieties, as they may have significant differences in both their effect on vegetation and soil (Béri et al. 2004). It is crucial to choose the breed according to the yield of the pasture and the quality of lawn management. Variety selection must take into account the animal's ability to grazing readiness, its abilities, and its weight (Nagy and Tasi 2017, Net1).

Indigenous breeds have important role in the grazing of protected areas (Gencsi 2005). According to Mihók (2005), the low-fertile grasslands can only be utilized with indigenous domestic species adapted to the domestic geographic conditions reasonably. The native Hungarian grey cattle was spread mainly in the plain lowlands (Kárpáti et al. 2004). Thanks to the "gentler" grazing of the Hungarian grey, the living conditions of several natural species may remain, which may give rise to richer pasture areas (Szentes et al. 2009a). The demand for natural food products is growing, which entails the growth of the Hungarian economic importance of grey cattle. This breed is less suitable for fattening and slaughter, because it has a medium-sized growth potency, and does not exhibit good meat patterns. On the contrary, beef market my accept crossbreeds from extensive farms due to water scarcity (Halász 2016). It is not competitive with the world production breeds, but today it is a major 
animal of the national parks, nature conservation and rural development programs (Net1).

Among the intensive varieties, charolais is one of the world's best beef cattle breeds because of its excellent properties, growing ability and meat quality. It is well adapted to the most varied areas, whether dry or wet, plain or mountainous. Because of their large body mass, they need a greater amount of grass, and are also more demanding on the quality of the feed. They play a smaller role in lawn management for nature conservation, although they have many properties (excellent pasture, feed utilization and adaptation to extreme conditions) that favour sustainable grazing. They are suitable primarily for the grazing of dry areas. Since they are large-scale species, they have a significant impact on soil and vegetation, especially in wet areas (Net2). Types of variety also include, in extensive and intense conditions, the decisive majority of the quality features that make the variety a world-class - with excellent fatigue, cutting properties and favourable meat shapes.

Grazing affects the species composition of the lawn, the trampling affects the grass: the proportion of the grass, the spread of the weeds and the amount of Fabaceae (Nyárai Horváth et al. 2005). According to Bánszki (1988) "the nutrient content of the lawn varies considerably according to the plant groups of the lawn and the quantity and proportion of species and varieties within the plant groups". Differences between the species can be caused by the specie's fibrillation susceptibility, the foliage and the stem ratio (Horn et al. 2006). In addition, there is considerable variation in the protein content among herbaceous plant species (Martin et al. 1972). The Fabaceaes are larger; the lawns have a more moderate protein content (Schmidt 1996).

The examination of feed quality is of great importance in the first growth, because most grasses only develop stems at that time (Steinwidder 2001). Martin et al. (1972), the fresh lawn must contain $18 \%$ dry matter, 20-26\% crude fibre, 16-23\% crude protein and $55 \%$ net energy concentration in the dry matter. In addition, the dry matter content was found to be highly volatile, mainly depending on the weather and the moisture conditions of the site, and that the dry matter content increases with the aging of the plants. Crude protein is one of the most important determinants of quality. The protein content of the grasslands depends heavily on plant height and developmental phase. As we progress to the late stage of development, protein content decreases (Daccord 1998, Tasi and Barcsák 2001). Raw fibre content shows an aging trend with increasing tendency. The young grass, which is often used, is poorer than the rarely utilized, aged grass. The process involves a decrease in feed digestibility and net energy content. At ruminants, net energy is used to determine the energy value of the energy and feed values. The lifesustaining energy needs of animals include the energy necessary for the metabolism replacement (heart function, respiration, excretion, nervous system function) and the energy consuming, digesting and absorbing nutrients of life-saving feeding stuffs (Martin et al. 1972).

We have already mentioned that the value of meadows and pastures (nature conservation and grassland management) depends to a great extent on their botanical composition (Haraszti 1973, Barcsák and Kertész 1986, Winczeffy 1993, Bajnok et al. 2000, Kelemen et al. 2013). The reason for this is mainly due to differences in the nutritional content of grass-gramma species (Horn et al. 2006). Based on our previous research results (Kovácsné et al. 2017), both grazing, weed types and cattle have a significant effect on plant species, on the botanical composition of grasslands. Thus it became questionable whether the same effects also apply to the nutrient content of vegetation of the examined grasslands.

Our research is an area of nature conservation and agriculture that is closely linked to work under the LIFE + project (LIFE11 NAT/HU/000924, www. legelotavak.hu). The program significantly increases the number of pasture animals in the project area and introduces a nature conservation grazing system. We have been involved in this research at this point in the LIFE + program. The primary purpose of our study is to analyze the effect of pasture use on the pasture vegetation and the nutrient content of the smaller extensive and the greater intensive cattle in order to get an answer if a more profitable, more economical and more intensive varieties can fulfill the conservation grazing needs.

In the course of our work, we searched the answers for the following questions: (i) What is the impact of grazing, (ii) of different grasslands and (iii) different cattle species (Hungarian grey or intensive beef) on nutrient content of the vegetation of the grassland?

\section{MATERIALS AND METHODS}

\section{Study area}

The research was carried out in the Hortobágy National Park. The average annual temperature in the region is $9.5{ }^{\circ} \mathrm{C}$, with an average annual rainfall of $550 \mathrm{~mm}$ (Lukács et al. 2015). For our studies sites with similar soil, vegetation (sward composition, stage of development of grasses) and microterrain were chosen. During the baseline survey no significant differences were found between the soil parameters $(\mathrm{pH}$, water soluble salt content, organic nitrogen, nitrate nitrogen, organic carbon in humus). The 1200 hectares land grazed by Hungarian grey is located on the northern part of the Hortobágy, Pap-ere, belonging to the Máta puszta. Several major but highly degraded pastures can be found there, where the natural water movement is currently hampered by the presence of the Tonnás canal. This area was grazed by 540 Hungarian grey cattle and breeds (480 calves). The grazed area of the mixed genotype with intensive cattle grazing is located in the southern part of Hortobágy, at the village of Faluvéghalma at Zám. Zám-puszta is one of the most important representatives of the southern grasslands of the Hortobágy, with numerous plains and pastures. This 1100-hectare area was grazed by intensive crossbreed 
(charolais crossed hereford and limousine F1) from 550 cows and breeds (500 calves). The grazing intensity of the selected areas was lower $(0.25$ livestock/ha) than the year of treatment, from 2015 onwards. From that year the pastures were utilized with 0.46 livestock/ha intensity. The intensity of grazing was determined from the grazed area size and the livestock value of grazed animals.

\section{Examined types of grasslands}

Associations were selected along a moisture gradient, which were the following: wet saline marshes (Bolboschoenetum maritimi) and dry salt meadows (Beckmannion eruciformis) (Deák et al. $2014 \mathrm{ab}$ ). The salty swamps occur in the deeper lands, so they are underwater longer than the salty meadows, making them more peachy (Deák et al. 2014c). Typical species are Bolboschoenus maritimus, Eleocharis palustris and E. uniglumis, Agrostis stolonifera, Carex melanostachya and Potentilla reptans. Salty meadows occur in areas that are also well but slightly elevated. Typical species are Alopecurus pratensis, Agrostis stolonifera, in drier areas: Carex praecox, C. stenophylla and Festuca pseudovina.

\section{Sampling}

Our studies were carried out in May 2016 and May 2017, studying the vegetation of wet saline marshes (Bolboschoenetum maritimi) and drier saline meadows (Beckmannion eruciformis). In Pap-ere and Zám, we designated our sampling areas for the monitoring of the effect of grazing on $1 \times 8 \times 8 \mathrm{~m}$ sample, and $8 \times 8 \mathrm{~m}$ in control areas. At the same time, a vegetal sample was collected to determine nutrient content. A total of 16 samples/control areas were analyzed. One average sample were made per sample area which was cut out of the selected location at 10 places (point pattern), leaving a 6-7 cm stubble. Weende analysis of the cut patterns was carried out at the University of Debrecen MÉK's Agricultural Center Laboratory. The original dry matter content, crude protein, crude fat, ash and crude fibre contents are based on MSZ-6830.

\section{Data processing}

The name of the species follows the nomenclature of Király (2009). In the statistical analysis, an independent model t-test was compared for two groups, and two variables were analysed for univariate variance analysis followed by Tukey-Kramer post-hoc test. We compared the characteristics of the vegetation with the SPSS 22 program package for different bovine species (extensive or intensive beef, fixed factor), plant type (wet or dry grass, fixed factor) and treatment (low grazing pressure, elevated grassing pressure or control, fixed factor). 5\% significance level was calculated.

\section{RESULTS}

When all three effects (grazing, grassland type and cattle) were evaluated simultaneously, statistically significant effects could only be detected for lifesustaining net energy. It can be seen that in all types of breeds and bovine species the life-sustaining net energy (Table 1) increased in all cases after years. We could not detect any other effects on the investigated parameters.

The effect of the grazing, plant type and the cattle's interaction on the parameters examined

\begin{tabular}{|c|c|c|c|c|c|c|c|c|c|c|c|c|}
\hline \multirow[b]{2}{*}{ Examined parameters } & \multicolumn{2}{|c|}{ Extensive dry } & \multirow{2}{*}{$\begin{array}{c}\text { Extensive } \\
\text { dry } \\
\text { control }\end{array}$} & \multicolumn{2}{|c|}{ Intensive dry } & \multirow{2}{*}{$\begin{array}{c}\text { Intensive } \\
\text { dry } \\
\text { control } \\
\end{array}$} & \multicolumn{2}{|c|}{ Extensive wet } & \multirow{2}{*}{$\begin{array}{c}\text { Extensive } \\
\text { wet } \\
\text { control } \\
\end{array}$} & \multicolumn{2}{|c|}{ Intensive wet } & \multirow{2}{*}{$\begin{array}{c}\text { Intensive } \\
\text { wet } \\
\text { control }\end{array}$} \\
\hline & $\begin{array}{c}2016 . \\
\text { year }\end{array}$ & $\begin{array}{c}2017 . \\
\text { year }\end{array}$ & & $\begin{array}{c}2016 . \\
\text { year }\end{array}$ & $\begin{array}{c}2017 . \\
\text { year }\end{array}$ & & $\begin{array}{c}2016 . \\
\text { year }\end{array}$ & $\begin{array}{c}2017 . \\
\text { year }\end{array}$ & & $\begin{array}{c}2016 . \\
\text { year }\end{array}$ & $\begin{array}{c}2017 . \\
\text { year }\end{array}$ & \\
\hline Dry matter $(\mathrm{m} / \mathrm{m} \%)$ & 33.37 & 29.6 & 35.9 & 36.38 & 32.3 & 31.6 & 27.01 & 33.6 & 34.7 & 28.35 & 32.2 & 38.8 \\
\hline Crude protein $(\mathrm{m} / \mathrm{m} \%)$ & 9.86 & 13.7 & 12.7 & 10.71 & 13.4 & 14.3 & 10.21 & 10.6 & 10.8 & 11.63 & 13.3 & 12.3 \\
\hline Crude fibre $(\mathrm{m} / \mathrm{m} \%)$ & 31.71 & 29.8 & 28.1 & 29.51 & 31.7 & 34.1 & 27.92 & 31.2 & 33.2 & 29.34 & 29.5 & 32.8 \\
\hline $\begin{array}{l}\text { Life-sustaining net } \\
\text { energy (MJ/kg d.m.) }\end{array}$ & $4.53^{\mathrm{a}}$ & $4.95^{\mathrm{b}}$ & $4.84^{\mathrm{ab}}$ & $4.60^{\mathrm{a}}$ & $5.20^{\mathrm{b}}$ & $5.22^{\mathrm{ab}}$ & $4.54^{\mathrm{a}}$ & $4.97^{\mathrm{b}}$ & $4.81^{\mathrm{ab}}$ & $4.56^{\mathrm{a}}$ & $5.09^{\mathrm{b}}$ & $5.00^{\mathrm{ab}}$ \\
\hline
\end{tabular}

\section{The effect of grazing}

Grazing had an effect on crude protein and lifesustaining net energy content $(\mathrm{p}<0.001)$. The highest value for raw protein content was measured in 2017 $(12.75 \mathrm{~m} / \mathrm{m} \%)$, the lowest in lower dry matter yield in $2016(10.6 \mathrm{~m} / \mathrm{m} \%)$. The same trend is observed for the life-sustaining net energy content (Table 2). The highest value was obtained in 2017 (5.05 MJ/kg body weight), so in the area grazed for two years with a higher number of cattle, the lowest in 2016 (4.55 $\mathrm{MJ} / \mathrm{kg}$ body weight). However, no significant effect was found on either dry matter or crude fibre content.

\section{The effect of grassland type}

We did not have any significant effect on the examined parameters for different types of grassland (Table 3).

\section{The effect of the cattle breed}

The type of cattle showed a significant effect only in one case: on the life-sustaining net energy content $(\mathrm{p}<0.001)$. Greater value was measured in the area grazed with intensive cattle $(5.15 \mathrm{~m} / \mathrm{m} \%)$. For the other parameters, the differences were not statistically verified (Table 4). 
Impact of grazing on the examined parameters

\begin{tabular}{|c|c|c|c|}
\hline \multirow{2}{*}{ Examined parameters } & \multicolumn{3}{|c|}{ Grazing pressure } \\
\hline & Year 2016* & Year $2017 * *$ & Control*** \\
\hline Dry matter $(\mathrm{m} / \mathrm{m} \%)(\mathrm{m} / \mathrm{m} \%)$ & 31.27 & 31.93 & 35.25 \\
\hline Crude protein $(\mathrm{m} / \mathrm{m} \%)$ & $10.60^{\mathrm{a}}$ & $12.75^{\mathrm{b}}$ & $12.52^{\mathrm{a}, \mathrm{b}}$ \\
\hline Crude fibre $(\mathrm{m} / \mathrm{m} \%)$ & 29.62 & 30.55 & 32.05 \\
\hline Life-sustaining net energy (MJ/kg d.m.) & $4.55^{\mathrm{a}}$ & $5.05^{\mathrm{b}}$ & $4.97^{\mathrm{b}}$ \\
\hline
\end{tabular}

Note: * results of measurement of nutritional content of grassland areas (grazed over one year with higher cattle density), ** results of measurement of nutritional content in pasture areas of 2017 (grazed two years with higher cattle density), *** results of measurement of nutrient content in our control area of 2017 (excluded areas from two grazing seasons).

The effect of the plant type on the parameters examined

\begin{tabular}{lrr}
\hline \multicolumn{1}{c}{ Examined parameters } & \multicolumn{2}{c}{ Types of grassland } \\
\cline { 2 - 3 } Dry matter $(\mathrm{m} / \mathrm{m} \%)(\mathrm{m} / \mathrm{m} \%)$ & Wet grassland* & Drier grassland** \\
Crude protein $(\mathrm{m} / \mathrm{m} \%)$ & 32,90 & 30,95 \\
Crude fibre $(\mathrm{m} / \mathrm{m} \%)$ & 11,95 & 13,55 \\
Life-sustaining net energy $(\mathrm{MJ} / \mathrm{kg} \mathrm{d}$.m) & 30,35 & 30,75 \\
\hline
\end{tabular}

Note: * results of nutritional content of wetland with extensive and intensive cattle in 2017, ** the results of the nutritional content of the dry areas with extensive and intensive cattle in 2017.

Table 4

The effect of the bovine species on the examined parameters

\begin{tabular}{lcc}
\hline \multicolumn{2}{c}{ Examined parameters } & \multicolumn{2}{c}{ Cattle breed type } \\
\cline { 2 - 3 } & Extensive beef cattle* & Intensive beef cattle** \\
\hline Dry matter $(\mathrm{m} / \mathrm{m} \%)(\mathrm{m} / \mathrm{m} \%)$ & 31.60 & 32.25 \\
Crude protein $(\mathrm{m} / \mathrm{m} \%)$ & 12.12 & 13.35 \\
Crude fibre $(\mathrm{m} / \mathrm{m} \%)$ & 30.50 & 30.60 \\
Life-sustaining net energy (MJ/kg d.m.) & $4.96^{\mathrm{a}}$ & $5.15^{\mathrm{b}}$ \\
\hline
\end{tabular}

Note: $*$ the results of the nutritional content of dry and wet grasslands grazed by extensive cattle in 2017 , ** the results of the nutritional content of dry and wet grasslands grazed by intensive cattle in 2017 .

\section{DISCUSSION}

Based on our results we found that grazing had an impact on raw protein and life-sustaining net energy content. The highest crude protein content (12.75 $\mathrm{m} / \mathrm{m} \%$ ) was obtained in the area of grazing in the year 2017 , i.e. for two years, with a higher animal density, probably due to the increased coverage of Fabaceae species (Trifolium repens and Trifolium angulatum). This $23.9 \%$ crude protein content is considered to be very good for feeding (Opitz, 1994). Our protein fibre ratio was 1:2 which is consistent with the results of Vinczeffy (1998) and Tasi (2006) that the proteinfibre ratio reaches a favourable ratio of $1: 2$ in the majority of grasses in mid-May. For the life-sustaining net energy, the highest value is also measured in 2017 and the smallest in 2016. However, no significant effect was found on either dry matter or crude fibre content.

There was no significant difference between the grassland types.
Furthermore, it was found that there is no significant difference between the effects of the two bovine species on the parameters examined. Significant effects were observed only in the case of life-sustaining net energy: in the area of intensive beef cattle we received a higher value $(5.15 \mathrm{MJ} / \mathrm{kg}$ body weight) than in the area with extensive beef cattle (4.96 MJ/kg body weight). However, we could not detect a significant effect for the other parameters.

Our results have also shown that cattle grazing is of the utmost importance for the maintenance of both wet and mesophilous habitats. Based on our three-year study, we can say that grazing by both extensive and intensive cattle is suitable for managing saline habitats.

\section{ACKNOWLEDGEMENTS}

The publication is supported by the EFOP-3.6.3VEKOP-16-2017-00008 project. The project is cofinanced by the European Union and the European Social Fund. 


\section{REFERENCES}

Ángyán J.-Tardy J.-Vajnáné Madarassy A. (2003): Védett és érzékeny természeti területek mezőgazdálkodásnak alapjai. Mezőgazda Kiadó. Budapest.

Bajnok M.-Rostás M.-Tasi J. (2000): Néhány legelő és rét növényzetének értékelése a takarmányozás szempontjából. Állattenyésztés és Takarmányozás. 49: 247-256.

Bánszki T. (1988): Tápanyag-gazdálkodás. [In: Nagy Z.-Vargyas Cs. (szerk.) Gyepnövénytermesztés - gyeptakarmányhasznosítás.] Szombathely. 287-323.

Barcsák Z.-Kertész I. (1986): Gazdaságos gyeptermelés és hasznosítás. Mezőgazdasági Kiadó. Budapest. 20-90.

Béri B.-Vajna T.-né-Czeglédi L. (2004): A védett természeti területek legeltetése. [In: Nagy G.-Lazányi J. (szerk.) Gyepgazdálkodás. Gyepek az agrár- és vidékfejlesztési politikában.] DE ATC. Debrecen. 50-59.

Deák, B.-Valkó, O.-Alexander, C.-Mücke, W.-Kania, A.-Tamás, J.-Heilmeier, H. (2014b): Fine-scale vertical position as an indicator of vegetation in alkali grasslands - case study based on remotely sensed data. Flora. 209: 693-697.

Deák, B.-Valkó, O.-Török, P.-Tóthmérész, B. (2014a): Solonetz meadow vegetation (Beckmannion eruciformis) in EastHungary - an alliance driven by moisture and salinity. Tuexenia. 34: 187-203.

Deák, B.-Valkó, O.-Tóthmérész, B-Török, P. (2014c): Alkali marshes of Central-Europe Ecology, Management and Nature Conservation. [In: Shao, H. B. (ed.) Salt Marshes: Ecosystem, Vegetation and Restoration Strategies.] Hauppauge: Nova Science Publishers. 1-11.

Gencsi Z. (2005): Biogazdálkodás extenzív gyepeken. Gyepgazdálkodás. 97-101.

Halász A. (2016): A különböző korú magyar szürke szarvasmarha legelői viselkedése az időjárástól és legelőkínálattól függően, hagyományos legeltetés mellett. Doktori disszertáció. Debreceni Egyetem. Debrecen.

Halasz, A.-Nagy, G.-Tasi, J.-Bajnok, M.-Mikone, J. E. (2016): Weather regulated cattle behaviour on rangeland. Applied Ecology and Environmental Research. 14: 149-158.

Haraszti E. (1973): Az állat és a legelő. Mezőgazdasági Kiadó. Budapest.

Horn P.-Dér F.-Nagy J. (2006): Farmon tartott gímszarvasok táplálóanyag-szükségletének kielégítése legelőn. Hazai és nemzetközi tapasztalatok. Gyepgazdálkodási Közlemények. 4: $7-12$.

Kárpáti B.-Sarudi Cs.-Csorbai A.-Marton I. (2004): A magyar szürke szarvasmarha tartásának ökonómiai és környezetgazdálkodási elemzése. Acta Agraria Kaposváriensis. 8: 33-49.

Kárpáti L. (2007): Természetvédelem és állattenyésztés. Magyar Mezőgazdaság. 48: 5-6.

Kelemen, A.-Török, P.-Valkó, O.-Miglécz, T.-Tóthmérész, B. (2013): Mechanisms shaping plant biomass and species richness: plant strategies and litter effect in alkali and loess grasslands. Journal of Vegetation Science. 24: 1195-1203.

Király G. (2009): Új magyar füvészkönyv. Magyarország hajtásos növényei. Határozókulcsok. Aggteleki Nemzeti Park Igazgatóság. Jósvafö.

Kovácsné K. N.-Tóth K.-Radócz Sz.-Béri B. (2017): Különböző szarvasmarha fajták legeltetésének hatása hortobágyi mélyfekvésủ legelők botanikai összetételére. Agrártudományi Közlemények. 73: 57-63.
Lukács, B. A.-Török, P.-Kelemen, A.-Várbíró, G.-Radócz, Sz.Miglécz, T.-Tóthmérész, B.-Valkó O. (2015): Rainfall fluctuations and vegetation patterns in alkali grasslands. Selforganizing maps in vegetation analysis. Tuexenia. 35: 381-397.

Märtin, B.-Fröbe, B.-Roth, D.-Shulze, G. (1972): Kleines abc Futterpflanzen. Deutscher Landwirtschaftsverlag. Berlin. 372.

Mihók S. (2005): Az állattenyésztés és a gyepgazdálkodás kapcsolata. [In: Jávor A. (szerk.) Gyep-Állat-Vidék-KutatásTudomány.] DE ATC. Debrecen. 55-62.

MSZ 6830-11:1999: Takarmányok táplálóértékének megállapítása. A peroxidszám és a savszám meghatározása.

Nagy G.-Tasi J. (2017): A legelők és a legeltetés szerepe a húsmarhatartásban. Állattenyésztés és Takarmányozás. 66: 347-364.

Net1: http://www.pannongyep.hu

Net2: http://www.grazinganimalsproject.org.uk/breed_profiles_ handbook.html

Nyárai Horváth F.-Póti P.-Tasi J. (2005): A környezetkímélő ökológiai gazdálkodás lehetőségei és gyakorlata a kérődző állatok tartásában. Egyetemi jegyzet. Szent István Egyetem. Gödöllő.

Opitz, V.-Boberfeld, W. (1994): Grünlandlehre. Biologische und ökologische Grundlagen. Verl. Eugen Ulmer. Stuttgart.

Penksza K.-Házi J.-Tóth A.-Wichmann B.-Pajor F.-Gyuricza Cs.Póti P.-Szentes Sz. (2013): Eltérő hasznosítású szürke marha legelő szezonális táplálóanyag tartalom alakulása, fajdiverzitás változása és ennek hatása a biomassza mennyiségére és összetételére pannon nedves gyepben. Növénytermelés. 62: 7394.

Penksza K.-Szentes Sz.-Loksa G.-Dannhauser C.-Házi J. (2010): A legeltetés hatása a gyepekre és természetvédelmi vonatkozásai a Tapolcai- és a Káli-medencében. Természetvédelmi Közlemények. 16: 25-49.

Schmidt J. (1996): Takarmányozástan. Mezőgazda Kiadó. Budapest. 151-152.

Steinwidder, A. (2001): Aspekte zur Weidehaltung von Milchkühen. Viehwirtschatliche Fachtagung. BAL gumpenstein. 53-68.

Szabó G.-Zimmermann Z.-Bartha S.-Szentes Sz. -Sutyinszki Zs.Penksza K. (2011): Botanikai, természetvédelmi és gyepgazdálkodási vizsgálatok Balaton-felvidéki szarvasmarhalegelőkön. Tájökológiai Lapok. 9: 431-440.

Szabó G.-Zimmermann Z.-Szentes Sz.-Sutyinszki Zs.-Penksza K. (2010/11): Természetvédelmi és gyepgazdálkodási vizsgálatok a Dinnyési-fertő gyepeiben. Gyepgazdálkodási Közlemények. 8: 31-38.

Szentes Sz.-Tasi J.-Wichmann B.-Penksza K. (2009a): Botanikai és gyepgazdálkodási vizsgálatok 2008. évi eredményei a badacsonytördemici szürkemarha legelőn. Gyepgazdálkodási Közlemények. 7: 73-78.

Tälle, M.-Deák, B.-Poschlod, P.-Valkó, O.-Westerberg, L.Milberg, P. (2016): Grazing vs. mowing: a meta-analysis of biodiversity benefits for grassland management. Agriculture, Ecosystems \& Environment. 15: 200-212.

Tasi J. (2006): Gyepnövények fenofázisainak hatása a minőségre és a legelési sorrendre. Doktori disszertáció. Gödöllő.

Tasi J.- Bajnok M.-Halász A.-Szabó F.-Harkányiné Sz. Zs.- Láng V. (2014): Magyarországi komplex gyepgazdálkodási adatbázis létrehozásának első lépései és eredményei. Gyepgazdálkodási Közlemények. 12: 57-64. 
Tölgyesi, Cs.-Bátori, Z.-Erdős, L.-Gallé, R.-Körmöczi, L. (2015): Plant diversity patterns of a Hungarian steppe-wetland mosaic in relation to grazing regime and land use history. Tuexenia. 35: 399-416.

Török, P.-Valkó, O.-Deák, B.-Kelemen, A.-Tóthmérész, B. (2014): Traditional cattle grazing in a mosaic alkali landscape: Effects on grassland biodiversity along a moisture gradient. PLoS ONE. 9. 5: e97095.

Tóth, E.-Deák, B.-Valkó, O.-Kelemen, A.-Miglécz, T.Tóthmérész, B.-Török, P. (2016): Livestock type is more crucial than grazing intensity: Traditional cattle and sheep grazing in short-grass steppes. Land Degradation \& Development.
Valkó, O.-Zmihorski, M.-Biurrun, I.-Loos, J.-Labadessa, R.Venn, S. (2016): Ecology and conservation of steppes and semi-natural grasslands. Hacquetia. 15: 5-14.

Vinczeffy I. (1993b): A gyep termése. [In: Legelő és gyepgazdálkodás.] Mezőgazda Kiadó. Budapest. 127-134.

Vinczeffy I. (1998): Lehetőségek a legeltetéses állattartásban. DATE. Debrecen. 134. 